\title{
Does Culture Play a Role on Underpricing? A Study on 47 Capital Markets
}

\author{
Orhan Emre Elma \\ Faculty of Applied Sciences, Necmettin Erbakan University, Konya, Turkey
}

\begin{abstract}
Culture can be defined as all living and thinking assets that separate one country from others. These material and spiritual features that come from the past and encompass the future determine the viewpoints and characteristics of nations. Although increasing globalization with the influence of the internet age brings each society a little closer, the cultural differences of the countries are preserved. In recent studies, the influence of culture has been observed in the fields of personal finance and capital markets, as well as in other areas of life. Initial public offerings are a way for companies to enter capital markets and this is a turning point for many firms. Companies initiate IPOs in order to increase their prestige, enhance their exporting volume, or maintain a better position among their competitors. It is important to manage this process efficiently with the appropriate pricing. Considering the public offerings that take place worldwide, underpricing draws attention almost anywhere. Underpricing, which is the difference between the public offering price and the first day closing price, has found wide coverage in the financial literature. Although, studies on the role of culture in underpricing have increased only in recent years. In this study, the potential cultural impact on underpricing in the initial public offerings at 47 countries was measured by the cultural dimensions of Hofstede. Results show that, power distance and underpricing has positive relationship at the level of $39 \%$, with 0.01 significance. In countries where democracy hasn't felt enough and inequality has increased, underpricing has been boomed due to the faulty trust among capital market players. In addition, 32.6\% negative relationship was determined between individualism and underpricing, with 0.05 significance. Compared to countries where individuals are living in groups, it has been found that there is less underpricing at countries where individuals are more confident personally. Also, in the regression analysis of Hofstede's six cultural dimensions, it was observed that the power distance explained the underpricing by $39 \%$. Keywords: Financial Markets, Underpricing, Cultural Dimensions.
\end{abstract}

DOI: $10.7176 /$ RJFA/11-6-06

Publication date:March $31^{\text {st }} 2020$

\section{Introduction}

Every country has a different cultural background, that reflects its citizens' day-to-day decisions. However some researchers (Dann, 1993) argue that every citizen is now sharing some of the same logic and priority of the foreigners, thanks to globalization. Because of world wide use of internet, once very different nations are getting closer to each other. But still, countries have their distinctions. Researchers found that these differences are coming from either complexity of the human nature (De Mooij and Beniflah, 2016), or the diversified ethnic, political and religious frames (Hofstede, 2005).

Even though defining culture quantitatively started at 1961 (Kluckhohn and Strodtbeck, 1961), most researchers analyzed cultures with county by country comparisons (Rosenbaum and Spears, 2005). After the internet boom at 21 st century and with the help of technology and globalization, scientists accepted the idea that culture can be measured. And scholars developed models to interpret different cultures (Jenner et. al, 2008). In an important study, it was examined how the parameters that individuals attach importance to in the workplace were affected by their cultural backgrounds (Hofstede, 1980). Also the same scientist has defined culture as the main components that distinguish a group of people from others (Hofstede, 2011).

This study addresses the underpricing phenomenon on capital markets with trying to answer the basic question, does national culture explain underpricing of initial public offerings and investors behaviors. 42055 initial public offerings that realized in 47 countries between 1959 and 2014 from Ritter's framework (Loughran et al., 1994) has been analyzed with Hofstede's cultural dimensions of these 47 countries (Hofstede, 2017). This study contributes to the cultural studies on IPOs and their predictive factors on underpricing.

\section{IPO Underpricing}


Public offering is an important milestone for many firms who want to grow and become an established public multipartnered organization. There are many reasons and motivations for companys to take the decision of going public. Raising funds through external sources (Pagano et al., 1998), enhancing negotiating position for future financial transactions (Rajan, 1992), amplifying firms' prestige (Ritter and Welch, 2002), decreasing capital cost (Scott, 1976), increasing benefits for the stock holders (Chemmanur and Fulghieri, 1999), confirming current market value (Ellingsen and Rydqvist, 1997) can be classified as the reasons behind the companies desire for being listed in the financial stock markets.

The difference between the public offering price and the closing price on the first day is called underpricing in the literature (Ibbotson, 1975). The underpricing of IPOs have been scrutinized starting from the study of Stoll and Curley (1970). Since then, more researchers have been questioning the reasons behind underpricing of IPOs. Some researchers have stated that this syndrome is caused by the difference of information between investors (Rock, 1986). In the markets where information asymmetry exists, the investors who do not have enough information decide on low-quality IPOs, while informed investors prefer initial public offerings with high potential.

Underpricing in capital markets is also explained by the signal theory (Grinblatt and Hwang, 1989). Companies are deliberately paving the way for underpricing in order to leave a better taste in the mouth of investors. According to this theory, firms want to start an efficient journey on capital markets by attracting more investors' attention at the start and creating a magnetic effect. In addition, the cost of underpricing is less for large and high quality firms than for small and new firms. This situation attracts investors to IPOs that have more underpricing. Those who advocate this theory state that there is a direct proportion between underpricing and the quality of the company.

Underwriters play a key role as intermediaries in the initial public offering process. Some of the studies on underpricing in the literature have focused on underwriters because of both their liquidity and price stability tasks in public offerings (Loughran and Ritter, 2002). Attracting investors with lower underpricing and more accurate pricing through more established and reputable underwriters is advocated as a public offering strategy for companies by researchers. In addition, having high market share and being consortium leader could affect the degree of underpricing, when it comes to underwriters. Firm or country specific reasons also effect underpricing (An and Chan, 2008).

The underpricing reasons vary according to countries economical and political backgrounds. Even though underpricing can be perceived distinctivelty at different countries, this phenomenon can still gives an insight about the financial capital markets. In a study, the potential impact of corporate governance changes between countries on public offerings examined and it was concluded that underpricing is higher in countries with better corporate governance (Boulton, 2010). The relationships between social variables like cultural diversity and underpricing have been studied as a new trend in the literature. Having previously offered to the public in their original countries appears to be a factor that reduces underpricing for foreign issuance companies in diversified financial markets such as US (Chui et al., 2010).

\section{The Role of Culture on Underpricing}

Culture can be clarified the package of standards that shape people's psychology, behavior, habits and is specific to a particular country or group (Zhou et. al., 2019). In behavioral finance it is crucial to analyze investors feelings. Geert Hofstede's cultural dimensions are a way to benchmark cultures with six different criterias (Han et al., 2010).

Hofstede (1980), conducted a research on IBM employees from more than 70 countries, and used four criterias in order to point out their differences and create a national culture map. These criterias are stemming from problems that arise in all societies. They are also in harmony with the Kluckhohn and Strodtbeck's (1961) first quantitative cultural research. The first 4 criterias are; power distance, individualism, masculanity, and uncertainty avoidance. Long term orientation and indulgence criterias are added to the model afterwards (Hofstede and Bond, 1988).

Power Distance evaluates equality and inequalities among citizens. If people believe that power is not distributed equally among citizens, then the power distance arises. At countries with high power distance scores, people tend to accept hierarchical orders with ease and they don't demand for equality. At low power distance countries, people prefer to fight for inequalities and they request more equilibrium in their lives. Studies on power 
distance show that individuals have less social trust in societies where more hierarchy is in operation, therefore, in capital markets where there are conflicts of interest, firms prefer more underpricing to increase their attractiveness and to maintain a healthy issuance process (Grinblatt and Huang, 1989).

Individualism criteria concentrates on group interests among people. This dimension interprets peoples' perspectives about whether or not taking care of others is substantial for them. At countries which has higher scores of individualism, people lean towards mosty taking care of themselves and their families. At lower degree individualism countries, people prefer the safety of being in a group, and consequently they look after their relatives and group members. In the studies examining the individuality dimension, it is observed that in higher individualism countries, individuals appreciate the implementation of risky strategies if companies have some future benefits from them (Griffin et al., 2013). From this point of view, companies play it more safely in countries with low individuality and agree to be offered with aggressive underpricing in order to realize a more successful issuance.

Masculinity measures a countrys' position when it comes to gender inequalities. Leadership, heroism and success coming with harsh feeling is important for more masculine nations. Competitiveness is the characteristic feature of these countries. On the other hand, some nations prefer more synergy, group thinking, togetherness and life quality. Cooperation is the hallmark of feminine nations. Researches on masculinity dimension shows that, at countries with higher masculinity ratings, managers with higher self-confidence implement excessive rate of underpricing, believing that they will earn sufficiently after issuance (Lougran \& Ritter, 2002). According to another study, men were found to be more likely to take risks than women, especially when it comes to financial decisions (Powell \& Ansic, 1997). Since it is directly proportional to taking risks, overdose of underpricing is expected in countries with higher masculinity.

Uncertainty avoidance criteria demonstrates how members of a country reacts when uncertainty and ambiguity appears. Some nations are at peace with their future, even though they don't fully know what will happen next, they prefer to concentrate on their present day and live their lives as they come. However, the situation is completely different at risk averse countries; people try to control their future, live with principles, don't accept new ideas or concepts with ease. Companies which are seeking to minimize risk aversion in their investors, especially use experienced bankers and underwriter firms in their issuances. A study shows that an increase in the number and status of the brokerage firms has decreased the exposure of stocks to underpricing (Carter \& Manaster, 1990). Additionally, another research clarified that public offerings, which are not seen as risky as others, are underpriced less (Ritter, 1984).

Long term orientation dimension expresses how a nation deals with change against tradition. Norms and past habits are vital for some countries. This type of nations' members mostly believe that truth is absolete, and they resist change. Conversely, some countrys are more adaptive and dynamic when it comes to change. People believe in freedom of thought and think that truth is relative. And finally, indulgence factor displays whether individuals of a society live through their lives with the sole purpose of enjoyment or strictness. Process of enjoying life to the limit is substantial for the members of high indulgence societies. These people tend to spend more money, and ultimately increase the level of supply and demand. In other respects, at low indulgence countries people tend to underrate pleasure and overrate social norms and rules. Individuals of these societies prefer spending less money.

According to previous researches, cultural background has a potential of affecting investors' perception of legal protection, portfolio preferences and returns, dividend payout ratios as well as underpricing of initial public offerings. There are many studies based on the fact that culture plays a very vital role in forming the basis of the financial systems of countries (Kwok and Tadesse, 2006; Aggarwal and Goodell, 2009). For example, the financial systems of the countries, which consist of individuals who like to avoid risks and can be described financially as safe investors, are mostly based on the banking system. Chang and Noorbakhsh (2009) and Ramirez and Tadesse (2009) conducted studies showing that culture affects the level of cash retention in individuals. Chui et al. (2010), on the other hand, based on Hofstede's individualism criteria, examined the role of culture in differentiating investment returns between countries. 


\section{Methodology}

42.055 IPOs listed at 47 countries are analyzed with each countrys' cultural dimension scores. The IPO statistics of countries are taken from Ritter's framework (Loughran et al., 1994), and the cultural dimensions are provided from Hofstede (2017). Average underpricing is about $31.67 \%$ among these countries. At this study whether culture has an effect on IPO underpricing is examined through regression and correlation analysis.

China and Saudi Arabia are among the countries where the most underpricing is observed, according to Table 1. Underpricing in China is found to be at $118.40 \%$, between 1990 and 2013 . The fact that China is the largest socialist country in the world and there is a direct or indirect state effect in most economic activities makes underpricing more observable in its own capital market. In addition, the availability of state-owned IPO issuance by either central or local governments puts this country in a different category.

Chinese government has made great efforts to initiate the process of public offering, within the context of economic program that began in the late 1970s (Sun and Tong, 2003). Although the underpricing in the country has decreased over time since this period, it is still at very high levels compared to the rest of the world. In furtherance, Jones et al. (1999) specifies that state-owned IPOs can have the luxury of cutting prices harshly for political and economic reasons without paying too much attention to the IPO return, but private companies can not accept losing one penny during the issuance.

On the other hand, underpricing in Saudi Arabia is more severe when compared to the rest of the world. In Gulf states, initial public offerings serve as a means of distributing wealth, and foreigners are prohibited from sharing the initial public offerings. This situation causes the markets to be shallower and increases underpricing. Another ban is that, foreign underwriters cannot lead the initial public offerings. Previous studies demonstrate that the banning of foreign investors from participating in the initial public offering could increase underpricing (Hopp and Dreher, 2013).

Austria and Denmark are the countries where the least power distance observed. The citizens of these countries don't believe in hierarchy and desires equality in terms of democracy. The underpricing level for these countries are $6.4 \%$ and $7.4 \%$ respectively. When it comes to individualism, United States and Canada are among the most individualist countries according to cultural dimension scores and their underpricing levels are $16.9 \%$ and $6.5 \%$, respectively.

According to Table 2, results show that correlation between power distance and underpricing is at 39\%, with the significance level of 0.01 . Countries with a powerful hierarchical order tend to have more underpricing. For example, China has a score of 80 at power distance index and its underpricing level is \%118.4. Also Saudi Arabia has a score of 95 at power distance index and its underpricing level is \%239.8.

Deriving from these results, it can be said that democracy have a positive effect on the efficiency of the markets. When individuals feel more secure and confident about their lives and their future, this social mood helps the market to price financial instruments more effectively.

Individualist countries have lower underpricing, compared to other countries. While United States has a score of 91 at individualism index, and has \%16.9 underpricing, South Korea has a score of 18 at individualism index and underpricing of $\% 58.8$.

Individualism ensures trust among investors, company managers and preexisting shareholders, so as a consequence, firms are priced more appropriately according to the market conditions. This is in line with also efficient markets hypothesis, where people have the possibility to access all publicly available information along with confidential information coming from insider trading. Transparency of capital markets, improves market liquidity and gives more confidence to both companies and new investors. However, masculinity, uncertainty avoidance, long term orientation and indulgence have no robust relationship with underpricing at this study. 
Table 1. Average Fist Day Returns of IPOs from 47 Countries and their Cultural Dimensions

\begin{tabular}{|c|c|c|c|c|c|c|c|}
\hline Country & PD & IND & $\mathbf{M}$ & UA & LTO & ING & Underpricing \\
\hline Argentina & 49 & 46 & 56 & 86 & 20 & 62 & $4.20 \%$ \\
\hline Australia & 36 & 90 & 61 & 51 & 21 & 71 & $21.80 \%$ \\
\hline Austria & 11 & 55 & 79 & 70 & 60 & 63 & $6.40 \%$ \\
\hline Belgium & 65 & 75 & 54 & 94 & 82 & 57 & $13.50 \%$ \\
\hline Brazil & 69 & 38 & 49 & 76 & 44 & 59 & $33.10 \%$ \\
\hline Bulgaria & 70 & 30 & 40 & 85 & 69 & 16 & $36.50 \%$ \\
\hline Canada & 39 & 80 & 52 & 48 & 36 & 68 & $6.50 \%$ \\
\hline Chile & 63 & 23 & 28 & 86 & 31 & 68 & $7.40 \%$ \\
\hline China & 80 & 20 & 66 & 30 & 87 & 24 & $118.40 \%$ \\
\hline Denmark & 18 & 74 & 16 & 23 & 35 & 70 & $7.40 \%$ \\
\hline Egypt & 70 & 25 & 45 & 80 & 7 & 4 & $10.40 \%$ \\
\hline Finland & 33 & 63 & 26 & 59 & 38 & 57 & $16.90 \%$ \\
\hline France & 68 & 71 & 43 & 86 & 63 & 48 & $10.50 \%$ \\
\hline Germany & 35 & 67 & 66 & 65 & 83 & 40 & $24.20 \%$ \\
\hline Greece & 60 & 35 & 57 & 100 & 45 & 50 & $50.80 \%$ \\
\hline Hong Kong & 68 & 25 & 57 & 29 & 61 & 17 & $15.80 \%$ \\
\hline India & 77 & 48 & 56 & 40 & 51 & 26 & $88.50 \%$ \\
\hline Indonesia & 78 & 14 & 46 & 48 & 62 & 38 & $24.90 \%$ \\
\hline Iran & 58 & 41 & 43 & 59 & 14 & 40 & $22.40 \%$ \\
\hline Ireland & 28 & 70 & 68 & 35 & 24 & 65 & $21.60 \%$ \\
\hline Italy & 50 & 76 & 70 & 75 & 61 & 30 & $15.20 \%$ \\
\hline Japan & 54 & 46 & 95 & 92 & 88 & 42 & $41.70 \%$ \\
\hline Jordan & 70 & 30 & 45 & 65 & 16 & 43 & $149.00 \%$ \\
\hline Korea & 60 & 18 & 39 & 85 & 100 & 29 & $58.80 \%$ \\
\hline Malaysia & 100 & 26 & 50 & 36 & 41 & 57 & $56.20 \%$ \\
\hline Mexico & 81 & 30 & 69 & 82 & 24 & 97 & $11.60 \%$ \\
\hline Morocco & 70 & 46 & 53 & 68 & 14 & 25 & $33.30 \%$ \\
\hline Netherlands & 38 & 80 & 14 & 53 & 67 & 68 & $10.20 \%$ \\
\hline New Zealand & 22 & 79 & 58 & 49 & 33 & 75 & $18.60 \%$ \\
\hline Nigeria & 80 & 30 & 60 & 55 & 13 & 84 & $13.10 \%$ \\
\hline Norway & 31 & 69 & 8 & 50 & 35 & 55 & $8.10 \%$ \\
\hline Pakistan & 55 & 14 & 50 & 70 & 50 & 0 & $22.10 \%$ \\
\hline Philippines & 94 & 32 & 64 & 44 & 27 & 42 & $18.10 \%$ \\
\hline Poland & 68 & 60 & 64 & 93 & 38 & 29 & $12.70 \%$ \\
\hline Portugal & 63 & 27 & 31 & 99 & 28 & 33 & $11.90 \%$ \\
\hline Russia & 93 & 39 & 36 & 95 & 81 & 20 & $3.30 \%$ \\
\hline Saudi Arabia & 95 & 25 & 60 & 80 & 36 & 52 & $239.80 \%$ \\
\hline Singapore & 74 & 20 & 48 & 8 & 72 & 46 & $25.80 \%$ \\
\hline South Africa & 49 & 65 & 63 & 49 & 34 & 63 & $17.40 \%$ \\
\hline Spain & 57 & 51 & 42 & 86 & 48 & 44 & $10.30 \%$ \\
\hline Sweden & 31 & 71 & 5 & 29 & 53 & 78 & $27.20 \%$ \\
\hline Switzerland & 34 & 68 & 70 & 58 & 74 & 66 & $27.30 \%$ \\
\hline Taiwan & 58 & 17 & 45 & 69 & 93 & 49 & $38.10 \%$ \\
\hline Thailand & 64 & 20 & 34 & 64 & 32 & 45 & $35.10 \%$ \\
\hline Turkey & 66 & 37 & 45 & 85 & 46 & 49 & $9.70 \%$ \\
\hline Unt. Kingdom & 35 & 89 & 66 & 35 & 51 & 69 & $16.00 \%$ \\
\hline United States & 40 & 91 & 62 & 46 & 26 & 68 & $16.90 \%$ \\
\hline
\end{tabular}

Source: Loughran, T., Ritter, J.R., \& Rydqvist, K. (1994). "Initial Public Offerings: International Insights", Pacific-Basin Finance Journal, 2, 165-199 (The data has been updated in 2015 by the same author), and Hofstede, G. (2017). Cultural Dimensions/National Culture $<\underline{\text { hofstede-insights.com/ }>}$ 
Table 2: Correlations Between Underpricing and Hofstede's' Cultural Dimensions of 47 Countries

\begin{tabular}{|c|c|c|c|c|c|c|c|c|}
\hline & Underpr. & PowerDist & Indiv. & Masc. & Uncer. Av. & LTOrient. & Indulg. \\
\hline \multirow[t]{3}{*}{ Underpricing } & Pearson Cor. & 1 & $.390^{* *}$ & $-.326^{*}$ & .137 & -.021 & .047 & -.154 \\
\hline & Sig. (2-tailed) & & .007 & .025 & .359 & .891 & .753 & .302 \\
\hline & $\mathrm{N}$ & 47 & 47 & 47 & 47 & 47 & 47 & 47 \\
\hline \multirow[t]{3}{*}{ Power Distance } & Pearson Cor. & $.390^{* *}$ & 1 & $-.694^{* *}$ & .092 & .221 & .007 & $-.394^{* *}$ \\
\hline & Sig. (2-tailed) & .007 & & .000 & .540 & .136 & .961 & .006 \\
\hline & $\mathrm{N}$ & 47 & 47 & 47 & 47 & 47 & 47 & 47 \\
\hline \multirow[t]{3}{*}{ Individualism } & Pearson Cor. & $-.326^{*}$ & $-.694^{* *}$ & 1 & .037 & -.198 & -.079 & $.473^{* *}$ \\
\hline & Sig. (2-tailed) & .025 & .000 & & .806 & .183 & .598 & .001 \\
\hline & $\mathrm{N}$ & 47 & 47 & 47 & 47 & 47 & 47 & 47 \\
\hline
\end{tabular}

In order to find which cultural dimension variable effects underpricing robustly, a regression analysis has been implemented. Stepwise method has been chosen to eliminate insignificant variables. So the following model is formulated:

Underpricing $=\beta_{0}+\beta_{1} *$ Power Distance $+\beta_{2} *$ Individualism $+\beta_{3} *$ Masculinity $+\beta_{4} *$ Uncertainty Avoidance + $\beta_{5} *$ Long Term Orientation $+\beta_{6} *$ Indulgence $+\varepsilon$

According to the regression analysis power distance is the only variable which is statistically robust at explaining underpricing, as seen on Table 3. These findings are in accordance with previous studies (Costa et al., 2013; Chourou et al., 2018). It can be said that equality among people in terms of democracy, brings more stability to the financial markets. When individuals of the nation feels more secure, this makes the financial system more credible and efficient as a consequence.

Table 3: Regression Model about Underpricing Based on Cultural Dimensions of Hofstede

\begin{tabular}{|c|c|c|c|c|c|c|c|}
\hline \multirow[t]{2}{*}{ Model } & \multicolumn{2}{|c|}{ Unstandardized Coefficients } & \multirow{2}{*}{\begin{tabular}{|l} 
Standardized Coefficients \\
Beta
\end{tabular}} & \multirow[t]{2}{*}{$\mathrm{t}$} & \multirow[t]{2}{*}{ Sig. } & \multicolumn{2}{|c|}{ Collinearity Statistics } \\
\hline & $\mathrm{B}$ & Std. Error & & & & Tolerance & VIF \\
\hline (Constant) & -.124 & .165 & & -.752 & 456 & & \\
\hline PowerDist & .008 & .003 & .390 & 2.840 & .007 & 1.000 & 1.000 \\
\hline
\end{tabular}

The results in this study showed that, apart from other internal and external market dynamics, only culture itself has an important and pivotal role in explaining the capital markets and investors behaviour. It is possible to predict the market performances companies that will enter a specific capital market, to a certain extent. Adding cultural dimensions according to cultural background of nations into underpricing analysis of different countries, may further strengthen the forecasts of shares' price trends.

\section{Conclusion}

Underpricing is a widely researched phenomenon which can be seen from undeveloped nations markets to developed countries stock exchanges. In theory, companies don't want to leave their money on the table, but still underpricing occurs. Plenty of factors could be in play as the literature suggests, ranging from underwriting agencies to the firms age when they became publicly listed. But in order to understand one nations stock market, could we also look at its cultural characteristics? This study tries to answer this question.

The power distance criteria focuses on the inequality felt among people. The increase in inequality brings a decrease in social trust throughout the society (Bjornskov, 2008). Increasing conflicts of interest and decreasing social trust among companies, underwriters and investors cause underpricing to be more severe (Chambers and Dimson, 2009). The individualism dimension concerns whether individuals who compose the society prefer to be in a group or not. Companies tend to make more underpricing at their IPOs, in order to attract more investors at 
issuance in countries with lower individualism. Such as, in China and Saudi Arabia, where individualism is lower, it is observed that companies do not strive to execute public offerings at higher prices, just like during the Internet bubble in US (Chen et al., 2015). For this reason, in countries where individualism is lower, underpricing is higher. At this research, no significant relationship was found between the other Hofstede cultural dimensions and underpricing.

In this study, the potential role of culture in the formation of underpricing syndrome was examined. In the cultural analysis of 47 countries' IPOs, only power distance and individualism criteria gave statistically significant results with underpricing. The relationship between underpricing and power distance is at $39 \%$, and significant at the level of 0.01 ; while the correlation between underpricing and individualism is at $-32.6 \%$, and significant at 0.05 level. In addition, the power distance criteria explains $39 \%$ of underpricing at the regression analysis. These results are in line with the previous literature examining the relationship between financial markets and culture (Chambers and Dimson, 2009; Zheng et al., 2013).

For further research, each country could be analyzed with supportive variables like legal background. The number of countries can be increased and they can be analyzed within different classifications based on their region and development level. The interaction between countries who has close trade relationships could be examined with foreign IPO performance at their capital markets. Results show that culture has an impact on underpricing, so cultural dimensions should be used in analyzing country specific capital markets.

\section{References}

Aggarwal, R. \& Goodell, J.W. (2009). "Markets and Institutions in Financial Intermediation: National Characteristics as Determinants", Journal of Banking and Finance, 33(10), 1770-1780.

An, H., \& Chan, K. (2008). “Credit Ratings and IPO Pricing”, Journal of Corporate Finance, 14, 584-595.

Bjornskov, C. (2008). "Social Trust and Fractionalization: A Possible Reinterpretation”, European Sociological Review, 24(3), 271-283.

Carter, R.B., \& Manaster, S. (1990). "Initial Public Offerings and Underwriter Reputation”, The Journal of Finance, 45, 1045-1067.

Chambers, D., \& Dimson, E. (2009). "IPO Underpricing Over the Very Long Run”, Journal of Finance, 64(3), 1407-1443.

Chang, K., \& Noorbakhsh, A. (2009). “Does National Culture Affect International Corporate Cash Holdings?”, Journal of Multinational Financial Management, 19(5), 323-342.

Chemmanur, T.J., \& Fulghiery, A. (1999). “Theory of the Going-Public Decision”, Review of Financial Studies, 12(2), 249-279.

Chen, Y., Wang, S.S., Li, W., Sun, Q., \& Tong W.H.S. (2015). "Institutional Environment, Firm Ownership, and IPO First-Day Returns: Evidence from China”, Journal of Corporate Finance, 32, 150-168.

Chourou, L., Saadi, S., \& Zhu, H. (2018). “How Does National Culture Influence Underpricing?”, Pacific-Basin Finance Journal, 51, 318-341.

Chui, A.C.W., Titman, S., \& John Wei, K.C. (2010). "Individualism and Momentum Around the World”, Journal of Finance, 65(1), 361-392.

Costa, B., Crawford, A., \& Keith, J. (2013). “Does Culture Influence IPO Underpricing?”, Journal of Multinational International Management, 23(1-2), 113-123.

Dann, G. (1993). "Limitations in the use of nationality and country of residence variables", in D. Pearce and R. Butler (Eds.): Tourism research: Critiques and challenges, 88-112, London: Routledge.

De Mooij, M., \& Beniflah, J. (2016). "Measuring Cross-Cultural Differences of Ethnic Groups within Nations: 
Convergence or Divergence of Cultural Values? The case of the United States", Journal of International Consumer Marketing, 29(1), 2-10.

Ellingsen, T., \& Rydqvist, K. (1997). "The Stock Market as a Screening Device and the Decision to Go Public", SSE Working Paper Series in Economics and Finance, 174, 1-30.

Griffin, D.W., Li, K., Yue, H., \& Zhao, L.R. (2013). “How Does Culture Influence Corporate Risk Taking?”, Journal of Corporate Finance, 23, 1-22.

Grinblatt, M., \& Hwang C. (1989). "Signaling and The Pricing of New Issues", Journal of Finance, 44, 393-420.

Han, S., Kang, T., Salter, S., \& Yoo, K. (2010). "A Cross-Country Study on the Effects of National Culture on Earnings Management Discretion”, Journal of International Business Studies, 41, 123-141.

Hofstede, G. (1980). “Culture's Consequences, International Differences in Work-Related Values”, Beverly Hills, CA: Sage Publications.

Hofstede, G., \& Bond, M.H. (1988). "The Confucius Connection: From Cultural Roots to Economic Growth", Organizational Dynamics, 16(4), 4-21.

Hofstede, G. (2005). Culture and organizations: Software of the mind”. New York, NY: McGraw-Hill.

Hofstede, G. (2011). "Dimensionalizing Cultures: The Hofstede Model in Context", Online Readings in Psychology and Culture, 2(1), 2-26.

Hofstede, G. (2017). "Cultural Dimensions, National Culture", < https://hofstede-insigths.com/>.

Hopp, C., \& Dreher, A. (2013). "Do Differences in Institutional and Legal Environments Explain Cross-Country Variations in IPO Underpricing?", Applied Economics, 45(4), 435-454.

Ibbotson, R.G. (1975). "Price Performance of Common Stock New Issues", Journal of Financial Economics, 2, $235-272$.

Jenner, S., MacNab, B., Briley, D., Brislin, \& R., Worthley, R. (2008). “Cultural Change and Marketing”, Journal of Global Marketing, 21(2), 161-274.

Jones, S.L., Megginson, W.L., Nash, R.C., \& Netter, J.M. (1999). "Share Issue Privatizations as Financial Means to Political and Economic Ends", Journal of Financial Economics, 53, 217-253.

Kluckhohn, F.R., \& Strodtbeck, F.L. (1961). "Variations in value orientations". Evanston, IL: Row, Peterson.

Kwok, C.C.Y., \& Tadesse, S. (2006). "National Culture and Financial Systems”, Journal of International Business Studies, 37(2), 227-247.

Loughran, T., Ritter, J.R., \& Rydqvist, K. (1994). "Initial Public Offerings: International Insights", Pacific-Basin Finance Journal, upd. (2015), 2, 165-199.

Loughran, T., \& Ritter, J.R. (2002). “Why Don't Issuers Get Upset About Leaving Money on the Table in IPOs?”, Review of Financial Studies, 15, 413-443.

Pagano, M., Panetta, F., \& Zingales, L. (1998). “Why Do Companies Go Public: An Empirical Analysis”, Journal of Finance, 53, 27-64.

Powell, M., \& Ansic, D. (1997). "Gender Differences in Risk Behaviour in Financial Decision-Making: An Experimental Analysis", Journal of Economic Psychology, 18, 605-628.

Rajan, R. G. (1992). "Insiders and Outsiders: The Choice between Informed and Arm's Length Debt”, Journal of Finance, 47(4), 1367-4000.

Ramirez, A. \& Tadesse S. (2009). "Corporate Cash Holdings, Uncertainty Avoidance, and the Multinationality of 
Firms", International Business Review, 18(4), 387-403.

Ritter, J.R. (1984). “The "Hot Issue" Market of 1980”, The Journal of Business, 57(2), 215-240.

Ritter, J.R., \& Welch, I. (2002). “A Review of IPO Activity, Pricing, and Allocations”, Journal of Finance, 57(4), $1795-1828$.

Ritter, J.R. (2003). "Differences between European and American IPO Markets”, Financial Management, 9(4), 421-434.

Rosenbaum, M., \& Spears, D. (2005). "Who Buys That? Who Does What? Analysis of Cross Cultural Consumption Behaviors among Tourists in Hawaii”, Journal of Vacation Marketing, 11(3), 235-247.

Scott, J. H. (1976). “A Theory of Optimal Capital Structure”, The Bell Journal of Economics, 7(1), pp. 33-54.

Sun, Q., \& Tong, W. (2003). “China Share Issue Privatization: The Extent of its Success”, Journal of Financial Economics, 70, 183-222.

Zheng, X., El Ghoul, S., Guedhami, O., \& Kwok, C.C.Y. (2013). "Collectivism and Corruption in Bank Lending”, Journal of International Business Studies, 44(4), 363-390.

Zhou, X., Cui, Y., Wu, S., \& Wang, W. (2019). “The Influence of Cultural Distance on the Volatility of the International Stock Market”, Economic Modelling, 77, 289-300. 